\title{
Effect of low-dose aspirin during pregnancy on fibrinolytic variables before and after parturition
}

\author{
Henk A. Bremer, MD, ${ }^{a}$ Nel Rotmans, BSc, ${ }^{a} \dagger$ Emile J.P. Brommer, MD, PhD, ${ }^{b}$ and \\ Henk C.S. Wallenburg, MD, PhD
}

Rotterdam and Leiden, The Netherlands

OBJECTIVE: We assessed the effects of a daily oral dose of 60 to $80 \mathrm{mg}$ of aspirin from 12 weeks' gestation until delivery on fibrinolytic variables before and after parturition.

STUDY DESIGN: In a prospective controlled study labor was electively induced in 24 patients, eight receiving low-dose aspirin and 16 controls. Levels were determined in maternal and cord plasma of tissue-type plasminogen activator antigen and activity, plasminogen activator inhibitor-1 antigen,

plasminogen activator inhibitor activity, and plasminogen activator inhibitor-2 antigen. We also determined metabolites of vascular prostacyclin and platelet thromboxane $A_{2}$.

RESULTS: The only maternal fibrinolytic variable affected by low-dose aspirin was plasminogen activator inhibitor activity, which showed a significant reduction before and after parturition of $40 \%$ and $70 \%$, respectively, in low-dose aspirin users compared with controls. Concentrations of thromboxane $B_{2}$ in women using low-dose aspirin were $7 \%$ (maternal serum) and $17 \%$ (cord serum) of values in controls, but concentrations of 6-keto-prostaglandin $F_{1 \alpha}$ were not affected.

CONCLUSIONS: Low-dose aspirin reduces plasminogen activator inhibitor activity and platelet reactivity, but not prostacyclin synthesis, before and after parturition. The reduction in plasminogen activator inhibitor activity may be caused by inhibition of platelet reactivity. (AM J OBSTET GrNECOL 1995;172:986-91.)

Key words: Fibrinolysis, low-dose aspirin, plasminogen activator, plasminogen activator inhibitor

In recent years an increasing number of pregnant women at risk of pregnancy-induced hypertensive disorders and fetal growth retardation are being prescribed low-dose aspirin, ${ }^{1}$ although its prophylactic effect remains disputed, ${ }^{2-4}$ Aspirin in analgesic doses may have an antifibrinolytic effect, because it inhibits the endothelial release of tissue-type plasminogen activator (tPA) after venous occlusion.5. 6 This effect could be mediated by inhibition of prostacyclin $\left(\mathrm{PGI}_{2}\right)$. synthesis because it is reversed by a synthetic $\mathrm{PGI}_{2}$ analog. ${ }^{7}$ Low-dose aspirin, $20 \mathrm{mg}$ for 7 days, did not afect fibrinolytic activity after venous occlusion in healthy males. ${ }^{8}$ Although low-dose aspirin primarily inhibits platelet thromboxane synthesis, it may also cause a small reduction in $\mathbf{P G I}_{2}$ synthesis in nonpregnant individuals ${ }^{9}$ and in pregnant women. ${ }^{10}$ For that reason an effect of long-term low-dose aspirin on the fibrinolytic

From the Institute of Obstetrics and Gynecology, Erasmus University School of Medicine and Health Sciences, ${ }^{a}$ and the Departments of Fibrinolysis and Proteolysis, Institute for Aging and Vascular Research, Gaubius Laboratory."

Received for publicalion March 3, 1994; revised August 8, 1994; accepted August 25, 1994.

Reprint requests: H.C.S. Wallenburg, $M D$, PhD, Institute of Obstetrics and Gynecology, EUR, Ee 2283, P.O. Box 1738, 3000 DR Rolterdam, The Netherlands.

tDeceased.

Copyright (1) 1995 by Mosby-Year Book, Inc.

$0002-9378 / 95 \$ 3.00+0 \quad 6 / 1 / 60267$ system of the pregnant woman cannot be excluded. Modulation of the fibrinolytic system by low-dose aspirin could be of particular importance after normal placental separation, when coagulation in the placental bed is balanced by a marked increase in fibrinolytic capacity."

In this study we compared variables of fibrinolysis and thromboxane and $\mathrm{PGI}_{2}$ synthesis at the end of pregnancy before and immediately after parturition in women receiving low-dose aspirin for prevention of preeclampsia or fetal growth retardation and in women who had not taken aspirin. Because exact definition of the timing of sampling could be important in an investigation on fibrinolytic variables, we conducted this study in plasma of women in whom labor was induced, which allowed standardization of sampling times. In addition, we investigated the effect of low-dose aspirin on fibrinolytic variables in cord blood.

\section{Material and methods}

Patients. Twenty-four healthy pregnant women were enrolled in the study. Of these, eight took a daily dose of 60 to $80 \mathrm{mg}$ of aspirin ( $1 \mathrm{mg} / \mathrm{kg}$ body weight) from 12 weeks' gestation until delivery because of a history of preeclampsia or fetal growth retardation; 16 women who did not usc aspirin during pregnancy served as controls. All women opted for elective induction of 
labor, an accepted procedure in the department. ${ }^{12}$ Cervical ripeness was assessed with the Burnhill score. ${ }^{13}$ When the cervix was considered favorable, the membranes were ruptured, and a fluid-filled open-tip catheter was introduced transcervically into the amniotic cavity for the recording of uterine activity. An electrode was attached to the fetal scalp for fetal heart rate monitoring. Uterine contractions were induced with intravcnous infusion of an incremental dose of oxytocin starting with $2 \mathrm{mU} / \mathrm{min}$ until a uterine activity of 150 to 200 Montevideo units was obtained. ${ }^{12}$ In all cases induction of labor started at 8 AM. Low-dose aspirin users took the last tablet at 7 AM. The study protocol as approved by the University and Hospital Ethics Committee was explained, and informed consent was obtained in all cases.

Blood sampling. Maternal venous blood samples were taken 5 minutes before the start of the oxytocin infusion and within 5 minutes after delivery of the placenta. All samples were obtained from an antecubital vein without occlusion through a 19-gauge needle.

A sample of $4.5 \mathrm{ml}$ was collected in tubes containing $0.5 \mathrm{ml}$ of $0.11 \mathrm{~mol} / \mathrm{L}$ sodium citrate, $15 \mathrm{mmol} / \mathrm{L}$ theophylline, $3.7 \mathrm{mmol} / \mathrm{L}$ adenosine, and $0.198 \mathrm{mmol} / \mathrm{L}$ dipyridamole, $\mathrm{pH} 5.5$ (Becton Dickinson, Meylan, France) for determination of tPA antigen, plasminogen activator inhibitor type-1 (PAI-1) and type-2 (PAI-2) antigen and plasminogen activator inhibitor activity. Another $4.5 \mathrm{ml}$ sample was collected in Stabilyte tubes (Biopool, Umea, Sweden, containing $0.5 \mathrm{ml}$ of $0.45 \mathrm{~mol} / \mathrm{L}$ sodium citrate buffer, $\mathrm{pH} 4.3$ ) for determination of tPA activity. A $9 \mathrm{ml}$ sample was taken in a plastic tube in $1 \mathrm{ml}$ of disodium ethylenediaminetetraacetate for determination of synthesis of malondialdehyde by stimulated platelets. For determination of 6-keto-prostaglandin $\mathrm{F}_{1 \alpha}\left(\mathrm{PGF}_{1 \alpha}\right)$, a stable metabolite of $\mathrm{PGI}_{2}$, a $5 \mathrm{mll}$ sample was collected in cooled plastic tubes containing $10 \mu \mathrm{l}$ of heparin and $25 \mu \mathrm{l}$ of indomethacin $(0.1 \%$ in potassium-phosphate buffer 0.1 $\mathrm{mol} / \mathrm{L}, \mathrm{pH}$ 7.4). Finally, a $5 \mathrm{ml}$ blood sample was collected in glass tubes and allowed to clot for determination of serum levels of thromboxane $\mathrm{B}_{2}\left(\mathrm{TXB}_{2}\right)$.

Samples of mixed free-flowing cord blood were collected immediately after clamping of the cord with the placenta in situ for determination of the same set of variables.

Analytic procedures. Samples for determination of variables of fibrinolysis were transported on melting ice, centrifuged for 30 minutes at $2000 \mathrm{~g}$ at $4^{\circ} \mathrm{C}$, and stored at $-70^{\circ} \mathrm{C}$ until analysis. Samples for detcrmination of plasma $\mathrm{PGF}_{1 \alpha}$ were centrifuged for 10 minutes at $1500 \mathrm{~g}$ at $0^{\circ} \mathrm{C}$ and stored at $-20^{\circ} \mathrm{C}$ until analysis. The clotted blood samples for determination of serum $\mathrm{TXB}_{2}$ were incubated for 60 minutes at $37^{\circ} \mathrm{C}$ to stimulate maximum platelet $\mathrm{TXB}_{2}$ release. After centrifugation for 10 minutes at $2500 \mathrm{~g}$ at $20^{\circ} \mathrm{C}$ serum samples were kept at $-20^{\circ} \mathrm{C}$ until analysis.

tPA antigen was determined with a commercially available enzyme immunoassay (Imulyse, Biopool) that measures both free and complexed $\mathrm{tPA}$ in the range of 1.5 to $30 \mathrm{ng} / \mathrm{ml}$. The maximal sensitivity of the test was $1.5 \mathrm{ng} / \mathrm{ml}$; intraassay variation was $8 \%$ and interassay variation $10 \%$.

tPA activity was determined by the conversion of plasminogen to plasmin in the presence of soluble fibrinogen fragments by means of a chromogenic substrate according to Verheijen et al. ${ }^{14}$ The detection limit of this assay was $50 \mathrm{mIJ} / \mathrm{ml}$; intraassay variation was $5 \%$ to $13 \%$, and interassay variation was $15 \%$ to $20 \%$.

PAI-1 antigen was measured with a commercially available enzyme immunoassay that used anti-PAI-1 antibodies (TintElize PAI-1, Biopool). The test measures both free PAI-1 and PAI-1 complexed to activators. The detection limit was $2 \mathrm{ng} / \mathrm{ml}$ PAI-1; the intraassay variation was $2 \%$ at $40 \mathrm{ng} / \mathrm{ml}$ and $7 \%$ at $15 \mathrm{ng} / \mathrm{ml}$.

PAI activity was measured by titration of diluted samples with tPA according to Verheijen et al. ${ }^{15}$ Results are expressed as a percentage of a standard normal plasma pool obtained from 40 healthy volunteers. Intraassay variation was $2 \%$ to $10 \%$, and interassay variation was $10 \%$ to $15 \%$.

PAI-2 antigen was determined with a commercially available enzyme immunoassay that used anti-PAI-2 antibodies (TintElize PAI-2, Biopool). The detection limit was $6 \mathrm{ng} / \mathrm{ml}$.

The capacity of platelets to synthesize thromboxane $A_{2}$ was determined within 30 minutes after venipuncture by measuring the amount of its stable by-product malondialdehyde produced on stirring platelet-rich plasma with thrombin ( $1 \mathrm{IU} / \mathrm{ml}$ final concentration), as described previously. ${ }^{16}$ The concentration of malondialdehyde was measured by means of the thiobarbituric acid reaction and expressed as nanomoles of malondialdehyde produced by $10^{9}$ platelets.

Plasma concentrations of $\mathrm{PGF}_{1 \alpha}$ and serum $\mathrm{TXB}_{2}$ levels were determined by radioimmunoassay (E.I. Du Pont de Nemours-NEN Research Products, Boston). A Sep-Pak $\mathrm{C}_{18}$ cartridge (Waters, Milford, Mass.) was prewashed with $10 \mathrm{ml}$ of absolute ethanol, $10 \mathrm{ml}$ of distilled water, and $2 \mathrm{ml}$ of air. Two milliliters of the sample was applied to the column, followed by $2 \mathrm{ml}$ of distilled water and $2 \mathrm{ml}$ of air. The prostaglandin metabolites were eluated with $2 \mathrm{ml}$ of absolute ethanol, followed by $2 \mathrm{ml}$ of air, and the eluate was brought to dryness at $40^{\circ} \mathrm{C}$ under a gentlc stream of nitrogen. The residue was dissolved in radioimmunoassay buffer, and the assay was performed with iodine 125-labeled antigen according to the instruction manual. ${ }^{17}$

Statistical analysis. Because the results could not be expected to follow a normal distribution, data are 
Table I. General characteristics of women who participated in the study (median, range)

\begin{tabular}{l|c|c}
\hline & Aspirin $(n=8)$ & Control $(n=16)$ \\
\hline Age (yr) & $32(26-38)$ & $30(20-41)$ \\
Parity & $1(1-1)$ & $1(1-7)$ \\
Duration of use of low-dose aspirin (wk) & $25.5(22-28)$ & - \\
Gestational age (wk) & $38.5(37.4-40.2)$ & $39.4(36.5-42)$ \\
Birth weight (gm) & $3305(2780-3715)$ & $3235(2670-4160)$ \\
Estimated blood loss at delivery (ml) & $200(100-600)$ & $200(100-1100)$ \\
\hline
\end{tabular}

Table II. Median (interquartile range) concentrations of variables of fibrinolysis in maternal venous plasma

\begin{tabular}{|c|c|c|c|}
\hline Plasma & Aspirin $(n=8)$ & Control $(n=16)$ & Significance* \\
\hline IPA antigen $(\mathrm{ng} / \mathrm{ml})^{\mathrm{a}}$ & $10.8(6.2-12.6)$ & $6.5(1.2 .16 .1)$ & NS \\
\hline tPA antigen $(\mathrm{ng} / \mathrm{ml})^{\mathrm{b}}$ & $17.6(14.9-27.2)$ & $13.9(10.5-29.3)$ & NS \\
\hline Significancet & $p=0.01$ & $p<0.001$ & \\
\hline tPA activity $(\mathrm{IU} / \mathrm{ml})^{\mathrm{a}}$ & $0.8^{P}(0.6-1.1)$ & $1.0(0.4-1.6)$ & NS \\
\hline tPA activity $(\mathrm{IU} / \mathrm{ml})^{\mathrm{b}}$ & $2.8(1.6-3.8)$ & $1.7(1.0-2.7)$ & NS \\
\hline Significancet & $p=0.01$ & $p=0.003$ & \\
\hline PAI-1 antigen $\left(\mathrm{ng} / \mathrm{ml}^{\alpha}\right.$ & $101.9^{P}(52.6-127.5)$ & $101.5(66.9-134)$ & NS \\
\hline PAI-1 antigen $(\mathrm{ng} / \mathrm{ml})^{\mathrm{b}}$ & $44.9(42.9-62.7)$ & $66.2(38.2-80.2)$ & NS \\
\hline $\begin{array}{l}\text { Significance } \\
\text { PAI-9 antigen }(\mathrm{ng} / \mathrm{ml})^{\mathrm{a}}\end{array}$ & $\begin{array}{c}p=0.01 \\
168\end{array}$ & $\begin{array}{c}p<0.001 \\
189(1344-9258)\end{array}$ & NS \\
\hline PAI-2 antigen $(\mathrm{ng} / \mathrm{ml})^{b}$ & $160.5(128.8-193.8)$ & $165.5(130.8-192.8)$ & NS \\
\hline Significancet & NS & $p=0.03$ & \\
\hline Plasminogen activator inhibitor activity $(\%)^{\mathrm{a}}$ & $326(86-428)$ & $556^{r}(431-829)$ & $p=0.02$ \\
\hline Plasminogen activator inhibitor activity $(\%)^{\mathrm{b}}$ & $108(70-167)$ & $339(100-528)$ & $p=0.02$ \\
\hline Significancet & $p=0.01$ & $p<0.001$ & \\
\hline
\end{tabular}

NS, Not significant.

*Aspirin versus control.

†Values obtained 5 minutes before oxytocin infusion (a) versus values 5 minutes after delivery of placenta $(b)$.

expressed as medians with 25th and 75th percentiles or range. Differences between time-related continuous variables were assessed with the Wilcoxon signed-rank test. Comparisons between maternal and cord samples and between aspirin and control groups were made with the Wilcoxon rank-sum test. Relationships between maternal and cord variables were analyzed with Spearman's rank correlation test. All $p$ values are two-tailed, and a level of $<0.05$ is considered to represent significance.

\section{Results}

General characteristics of the women who participated in the study are summarized in Table I. None of the aspirin-treated women had a pregnancy-induced hypertensive disorder or fetal growth retardation. All deliveries were uncomplicated and resulted in live, healthy infants.

Effects of labor and delivery on fibrinolytic markers are presented in Table II. Concentrations of tPA antigen, tPA activity, PAI- 1 antigen, and PAI-2 antigen before labor and after delivery of the placenta were not different between aspirin users and controls. Plasminogen activator inhibitor activity was significantly reduced in the aspirin group compared with controls, before and after parturition $(p=0.02)$.

Both TPA antigen and activity rose, whereas PAI-1 antigen and plasminogen activator inhibitor activity decreased significantly during labor and delivery. These changes were not affected by low-dose aspirin and were not related to the duration of labor. PAI-2 antigen showed a small but significant $(p=0.03)$ reduction during parturition in the control group that could not be demonstrated in low-dose aspirin users. No significant correlations were demonstrated between the levels of fibrinolytic variables in maternal and cord plasma. Comparison of fibrinolytic variables in cord blood in the aspirin and control groups showed no significant differences (Table III).

Levcls of PGF $_{1 \alpha}$ before labor in the aspirin group (median $54.7 \mathrm{ng} / \mathrm{L}$, range 52 to $82.8 \mathrm{ng} / \mathrm{L}$ ) were about $14 \%$ lower than in controls (median $63.3 \mathrm{ng} / \mathrm{L}$, range 50.6 to $73 \mathrm{ng} / \mathrm{L}$ ), but the difference was not significant. Fig. 1, A and $B$, shows the significant increase in $\mathrm{PGF}_{1 \alpha}$ in maternal plasma during parturition; no significant differences could be demonstrated between the aspirin and control groups. Cord plasma levels of PGF ${ }_{1 \alpha}$ were not different between groups and were about 14 times higher than maternal plasma concentrations $(p<0.001)$.

Before labor maternal malondialdehyde formation in the aspirin group (median $0.52 \mathrm{nmol} / 10^{9}$ platelcts, range 0.48 to $1.00 \mathrm{nmol} / 10^{9}$ platelets) and serum $\mathrm{TXB}_{2}$ concentrations (median $20.8 \mu \mathrm{g} / \mathrm{L}$, range 12.0 to 40.2 $\mu \mathrm{g} / \mathrm{L}$ ) were significantly lower than those in controls 

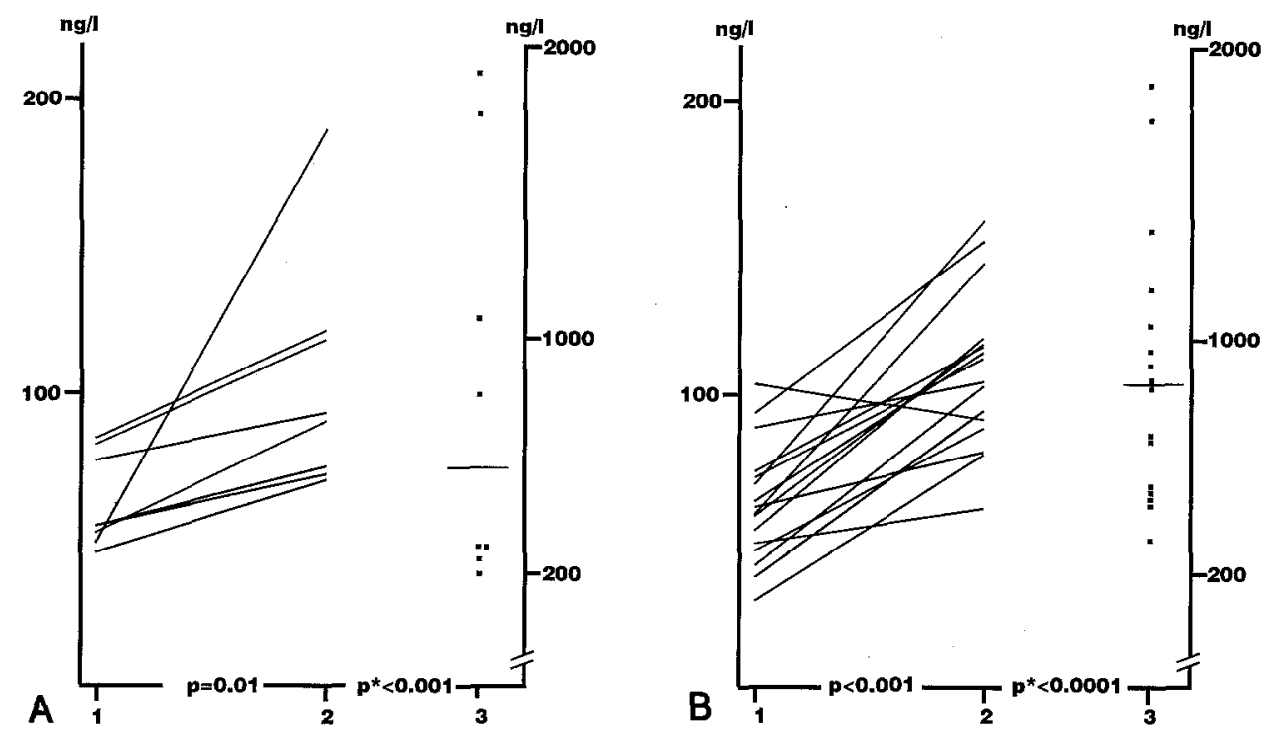

Fig. 1. $\mathbf{A}$ and $\mathbf{B}$, Maternal venous and cord plasma levels of $6-k e t o-P G F_{1 \alpha \alpha}$ in women receiving long-term low-dose aspirin (A) compared with controls not taking aspirin (B). 1, Before parturition; 2, after parturition; 3, cord plasma. Asterisk, Compared with maternal plasma 2.

Table III. Median (interquartile range) concentrations of variables of fibrinolysis and prostanoid mctabolites in cord blood

\begin{tabular}{|c|c|c|c|}
\hline & Aspirin $(n=8)$ & Control $(n=16)$ & Significance \\
\hline tPA antigen $(\mathrm{ng} / \mathrm{ml})$ & $4.5(2.3-26)$ & $4.5(3.2-7.5)$ & NS \\
\hline tPA activity (IU/ml) & $7.5(2.9-8.9)$ & $3.0(1.5-11)$ & NS \\
\hline PAI- 1 antigen $(\mathrm{ng} / \mathrm{ml})$ & $14.9(10.6-77)$ & $21.2(17.8-50)$ & NS \\
\hline Plasminogen activator inhibitor activity $(\%)$ & $43(25-100)$ & $49(23-78)$ & NS \\
\hline PAI-2 antigen $(\mathrm{ng} / \mathrm{ml})$ & $3.7(0.5-68.2)$ & $6.6(3.2-27)$ & NS \\
\hline 6-keto-PGF ${ }_{1 \alpha}(\mathrm{ng} / \mathrm{L})$ & $626(326-1164)$ & $862(471-1182)$ & NS \\
\hline $\operatorname{TXB}^{2}(\mu \mathrm{g} / \mathrm{L})$ & $37.8(27.7-80)$ & $217(123-326)$ & $p=0.0002$ \\
\hline Malondialdehyde (nmol $/ 10^{9}$ platelets) & $2.2(1.9-2.7)$ & $5.2(4.7-5.8)$ & $p=0.0001$ \\
\hline
\end{tabular}

NS, Not significant.

(malondialdehyde median $5.4 \mathrm{nmol} / 10^{9}$ platelets, range 4.7 to $6.4 \mathrm{nmol} / 10^{9}$ platelets; $1 \mathrm{XB}_{2}$ median $281 \mu \mathrm{g} / \mathrm{L}$, range 205 to $411 \mu \mathrm{g} / \mathrm{L} ; p<0.0001)$. No significant changes were observed in platelet malondialdehyde formation and in serum $\mathrm{TXB}_{2}$ concentrations during parturition in aspirin users and in controls.

In the control group no differences could be demonstrated between platelet malondialdehyde synthesis and serum $\mathrm{TXB}_{2}$ concentrations in maternal and cord samples, but in low-dose aspirin users malondialdehyde synthesis and serum $\mathrm{TXB}_{2}$ concentrations were significantly reduced in maternal compared with cord samples $(p<0.001)$.

\section{Comment}

Results of previous studies suggest that a daily dose of 60 to $80 \mathrm{mg}$ of aspirin has no demonstrable effect on hemostasis in pregnant women, as indicated by the bleeding time, ${ }^{18,}{ }^{19}$ but no data could be found in the accessible literature on the effect on the fibrinolytic system. Throughout pregnancy marked alterations occur in the fibrinolytic system, characterized by increases in plasma concentrations of tPA and its inhibitors PAI-1 and PAI-2 until the end of the thirty-eighth week of pregnancy, after which plasma concentrations of all these substances decrease, except those of tPA antigen. ${ }^{20}$ In a recent report on the effects of parturition on fibrinolysis a significant increase in maternal plasma concentrations of tPA antigen during labor was demonstrated, with a marked further increase in fibrinolytic potential after placental separation. ${ }^{21}$ In previous studies a high dose of aspirin (650 mg) ingested 18 and 2 hours before blood sampling was shown to inhibit the release of tPA antigen by vascular endothelium induced by venous occlusion. ${ }^{5,6} \mathrm{~A}$ study of the effect of $20 \mathrm{mg}$ of aspirin taken for 7 consecutive days showed no significant effect on fibrinolytic activity, measured by the euglobulin lysis area and the euglobulin lysis time. ${ }^{8}$ In our study no effect of the long-term use of low-dose aspirin on tPA activity was observed. The only fibrino- 
lytic variable affected by the use of low-dose aspirin during pregnancy was plasminogen activator inhibitor activity, which was significantly reduced in the aspirin group before and after labor. This could lead to a relative dominance of tPA activity over plasminogen activator inhibitor and hence to an increased fibrinolytic potential in low-dose aspirin users. The question whether this causes an increase in effective fibrinolysis in vivo remains to be answered. The observed signifcant changes in levels of all fibrinolytic markers during parturition, except PAI-2, may be caused by vascular damage in the uterine placental bed ${ }^{22}$ and appear to remain unaffected by low dose aspirin. In the nonpregnant state diurnal variations in blood fibrinolytic activity are caused by changes in the plasma levels of PAI-1, which are highest in the early morning and lowest in the late afternoon. ${ }^{23}$ However, plasminogen activator inhibitor production is not influenced by diurnal variations in populations with high plasminogen activator inhibitor levels, as in pregnancy. ${ }^{24}$ Because of the standardization of our study, all samples were obtained at approximately the same time of the day, which makes a contribution of circadian variation to the results unlikely.

We could not demonstrate an inhibitory effect of the long-term intake of 60 to $80 \mathrm{mg}$ of aspirin on nudernal $\mathrm{PGI}_{2}$ synthesis, which confirms earlier observations by ourselves ${ }^{25}$ and by others. ${ }^{18}$ The observed increased synthesis of $\mathrm{PGI}_{2}$ during labor confirms earlier observations ${ }^{26}$ and appears also to be unaffected by low-dose aspirin.

It is known that in normal pregnancy platelet reactivity increases, not only in association with increasing activity of the cyclooxygenase pathway but also with an elevated sensitivity of the platelet membrane. ${ }^{27}$ Previous studies have shown that approximately $90 \%$ to $95 \%$ inhibition of maternal platelet reactivity can be achieved with a daily dose of $60 \mathrm{mg}$ of aspirin, ${ }^{27,} 28$ as confirmed in the current study. Negatively charged phospholipids are known to stimulate plasminogen activator inhibitor activity, ${ }^{29}$ and platelets, offering a net negative charge on activation, may provide a site for activation of plasminogen activator inhibitor. ${ }^{30}$ Therefore the reduced platelet reactivity induced by low-dose aspirin could be responsible for the reduced plasminogen activator inhibitor activity in the aspirin group.

\section{REFERENCES}

1. Bremer HA, Wallenburg HCS. Low-dose aspirin in pregnancy: changes in patterns of prescription in thc Netherlands. Eur J Obstet Gynecol Reprod Biol 1993;52: 29-33.

2. Brcmer HA, Wallenburg HCS. Aspirin in pregnancy. Fetal Matern Med Rev 1992;4:37-57.

3. Italian study of aspirin in pregnancy. Low-dose aspirin in prevention and treatmem of intrauterine growth retardation and pregnancy-induced hypertension. Lancet 1993; 341:396-400.
4. Sibai BM, Caritis SN, Thom E, et al. Prevention of preeclampsia with low-dose aspirin in healthy, nulliparous prcgnant women. N Engl J Med 1993;329:1213-8.

5. Levin RI, Harpel PC, Weil D, Chang TS, Rifkin DB Aspirin inhibits vascular plasminogen activator activity in vivo. J Clin Invest 1984;74:571-80.

6. Levin RI, Harpel PC, Harpel JG, Recht PA. Inhibition of tissue plasminogen activator activity by aspirin in vivo and its relationship to levels of tissue plasminogen activator antigen, plasminogen activator inhibitor, and their complexes. Blood 1989;74:1635-43.

7. Bertelé V, Mussoni L, Pintucci G, et al. The inhibitory effect of aspirin on fibrinolysis is reversed by iloprost, a prostacyclin analogue. Thromb Haemost 1989;61:286-8.

8. De Gaetano G, Carriero MR, Cerletti C, Mussoni L. Low dose aspirin does not prevent fibrinolytic response to venous occlusion. Biochem Pharmacol 1986;35:3147-50.

9. FitzGerald GA, Oates JA, Hawiger J, et al. Endogenous biosynthesis of prostacyclin and thromboxane and platelet function during chronic administration of aspirin in man. J Clin Invest 1983;71:676-88.

10. Sibai BM, Mirro R, Chesney CM, Leffler C. Low-dose aspirin in pregnancy. Obstet Gynecol 1989;74:551-7.

11. Runnebaum IB, Maurer SM, Daly L, Bonnar J. Inhibitors and activators of fibrinolysis during and after childbirth in maternal and cord blood. J Perinat Med 1989;17:113-9.

12. Vierhout ME, Out JJ, Wallenburg HCS. Elective induction of labor: a prospective clinical study. I. Obstetric and neonatal effects. J Perinat Med 1985;13:155-62.

13. Burnhill MS, Danezis J, Cohen J. Uterine contractility during labor studied by intra-amniotic fluid pressure recordings. I. Effect of age, parity, duration of pregnancy, quality of the cervix, sedation, position, dose level, and amount of oxytocics on the course of labor. AM J OBSTET GYNECOL 1962;83:561-71.

14. Verheijen JH, Mullaart E, Chang GTG, Kluft C. A simple, sensitive spectrophotometric assay for extrinsic (tissue type) plasminogen activator applicable to measurements in plasma. Thromb Haemost 1982;48:266-9.

15. Verheijen JH, Chang GTG, Kluft C. Evidence for the occurrence of a fast acting inhibitor of tissue-type plasminogen activator in human plasma. Thromb Haemost 1981;51:392-5.

16. Wallenburg HCS, Van Kessel PH. Platelet life span in normal pregnancy as determined by a nonradioisotopic technique. Br J Obstet Gynaecol 1978;85:33-6.

17. Instruction manual for the measurement of 6-keto-prostaglandin $F_{1 \alpha}$ levels in tissue and biological fluids. Boston: E.I. Du Pont de Nemours, 1991.

18. Benigni A, Gregorini G, Frusca T, et al. Effect of low-dose aspirin on fetal and maternal generation of thromboxane by platelets in women at risk for pregnancy-induced hypertension. N Engl J Med 1989;321:357-62.

19. Williams HD, Howard R, O'Donnell N, Findley I. The effect of low dose aspirin on bleeding times. Anaesthesia $1993 ; 48: 331-3$

20. I indoff $C$, I erander I, Åstedt B. Fihrinolytic components in individual consecutive plasma samples during normal pregnancy. Fibrinolysis 1993;7:190-4.

21. Bremer HA, Brommer EJP, Wallenburg HCS. Effects of labor and delivery on fibrinolysis. Eur J Obstet Gynecol Reprod Biol 1994;55:163-8.

22. Yoshimura $T$, Ito $M$, Nakamura $T$, Okamura $H$. The influence of labor on thrombotic and fibrinolytic systems. Eur J Obstet Gynecol Reprod Biol 1992;44:195-9.

23. Kluft C, Jic AFH, Rijkcn DC, Vcrheijen JH. Daytimc fluctuations in blood of tissue-type plasminogen activator and its fast acting inhibitor PAI-1. Thromb Haemost 1988;59:329-32.

24. Juhan-Vague I, Alessi MC, Raccah D, et al. Daytime fluctuations of plasminogen activator inhibitor I (PAI-1) in populations with high PAI-1 levels. Thromb Haemost 1992;67:76-82.

25. Wallenburg HCS, Rotmans N. Prevention of recurrent 
idiopathic fetal growth retardation by low-dose aspirin and dipyridamole. AM J OBSTET GyNECOL 1987;157:1230-5.

26. Ylikorkala $\mathrm{O}$, Mäkäräinen $\mathrm{L}$, Viinikka L. Prostacyclin production increases during human parturition. Br J Obstet Gynaecol 1981;88:513-6.

27. Louden KA, Broughton-Pipkin F, Symonds EM, et al. $\Lambda$ randomized placebo-controlled study of the effect of lowdose aspirin on platelet reactivity and serum thromboxane $\mathrm{B}_{2}$ production in non-pregnant women, in momal pregnancy, and in gestational hypertension. Br J Obstet Gynaecol 1992;99:371-6.

28. Wallenburg HCS, Dekker GA, Makovitz JW, Rotmans N.
Effect of low-dose aspirin on vascular refractoriness in angiotensin-sensitive primigravid women. AM J OBSTET GYNFCOI 1991;164:169-73.

29. Lambers JWJ, Cammenga M, König BW, Mertens K, Pannekoek $\mathrm{H}$, van Mourik JA. Activation of human endothelial cell-type plasminogen activator inhibitor (PAI-1) by negatively charged phospholipids. J Biol Chem 1987;262: 17492-6.

30. Loskutoff DJ, Sawdey M, Mimuro J. Type 1 plasminogen activator inhibitor. In: Coller BS, ed. Progress in hemostasis and thrombosis. Philadelphia: WB Saunders, 1989: 87-115.

\title{
Angiotensin-converting enzyme activity and contractile effects of angiotensin I and II in human uteroplacental arteries
}

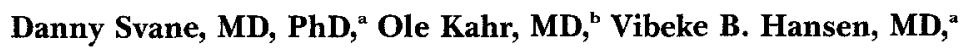 \\ Peter Holm-Nielsen, $\mathbf{M D},{ }^{\mathrm{c}}$ and Axel Forman, $\mathbf{M D}, \mathrm{PhD}^{\mathrm{a}}$ \\ Aarhus, Denmark
}

OBJECTIVE: Our purpose was to study local angiotensin-converting enzyme activity and the mechanical effects of angiotensin I and II in human uteroplacental arteries.

STUDY DESIGN: Angiotensin-converting enzyme activity was measured by a simple radioimmunoassay with tritiated benzoyl-glycyl-glycyl-glycine as substrate in isolated human intramyometrial arteries from nonpregnant $(n=8)$ and term pregnant women $(n=8)$ and placental $(n=8)$ stem villous arteries. Moreover, in these vessels the mechanical effects of angiotensin I and II were investigated in organ bath experiments. Endothelium-intact and endothelium-denuded arteries were used, and the integrity of the endothelium was examined by histologic studies.

RESULTS: The activity of angiotensin-converting enzyme ranked the intramyometrial arteries from pregnant women $>>$ intramyometrial arteries from nonpregnant women $>$ fetal stem villous arteries. Angiotensin-converting enzyme activity was unaffected by removal of the endothelium. Angiotensin $I 10^{-5}$ $\mathrm{mol} / \mathrm{L}$ produced contractile responses in the intramyometrial arteries without significant differences between arteries from nonpregnant and pregnant women. In fetal stem villous arteries the effects of angiotensin $1 / 10^{-5} \mathrm{~mol} / \mathrm{L}$ were less pronounced. As for angiotensin II, the contractile responses to angiotensin $110^{-5} \mathrm{~mol} / \mathrm{L}$ showed marked development of tachyphylaxis. In the endothelium-denuded preparations the contractile responses to angiotensin $110^{-5} \mathrm{~mol} / \mathrm{L}$ were significantly enhanced in intramyometrial arteries from nonpregnant women but remained unchanged in intramyometrial arteries from pregnant women and in fetal stem villous arteries. In all preparations pretreatment with captopril or perindopril $\left(10^{-5} \mathrm{~mol} / \mathrm{L}\right)$ markedly reduced angiotensin-converting enzyme activity, whereas no effects were observed on the contractile responses to angiotensin I. Saralasin $10^{-5} \mathrm{~mol} / \mathrm{L}$ completely abolished the contractile responses to angiotensin I and II.

CONCLUSION: Local angiotensin-converting enzyme activity in human intramyometrial arteries seems to be markedly increased during pregnancy and shows marked differences between maternal and fetal uteroplacental arteries. High concentrations of angiotensin I may imply direct effects on the angiotensin II receptor independent of the local angiotensin-converting enzyme activity. (AM J OBSTET GYNECOL 1995;172:991-7.)

Key words: Angiotensin-converting enzyme, radioimmunoassay, uteroplacental smooth muscle

From the Departments of Obstetrics and Gynecology, ${ }^{a}$ Pharmacology, ${ }^{b}$ and Pathology, ${ }^{C}$ University of Aarhus.

Supported by grants from the Danish Medical Research Council and the Danish Medical Assaciation's Fund.

Received for publication December 2, 1993; revised August 11, 1994; accepted August 25, 1994.
Reprint requests: Danny Stane, $M D, P h D$, Department of Obstetrics and Gynecology, Aarhus Municipal Hospital, University of Aarhus, DK-8000 Aarhus C, Denmark.

Copyright (Q) 1995 by Mosby-Year Ronk, Ino

$0002-9378 / 95 \$ 3.00+0 \quad 6 / 1 / 60264$ 